Hydraulic Analysis of Chenango River, Broome County, New York, in relation to State Highway Plan

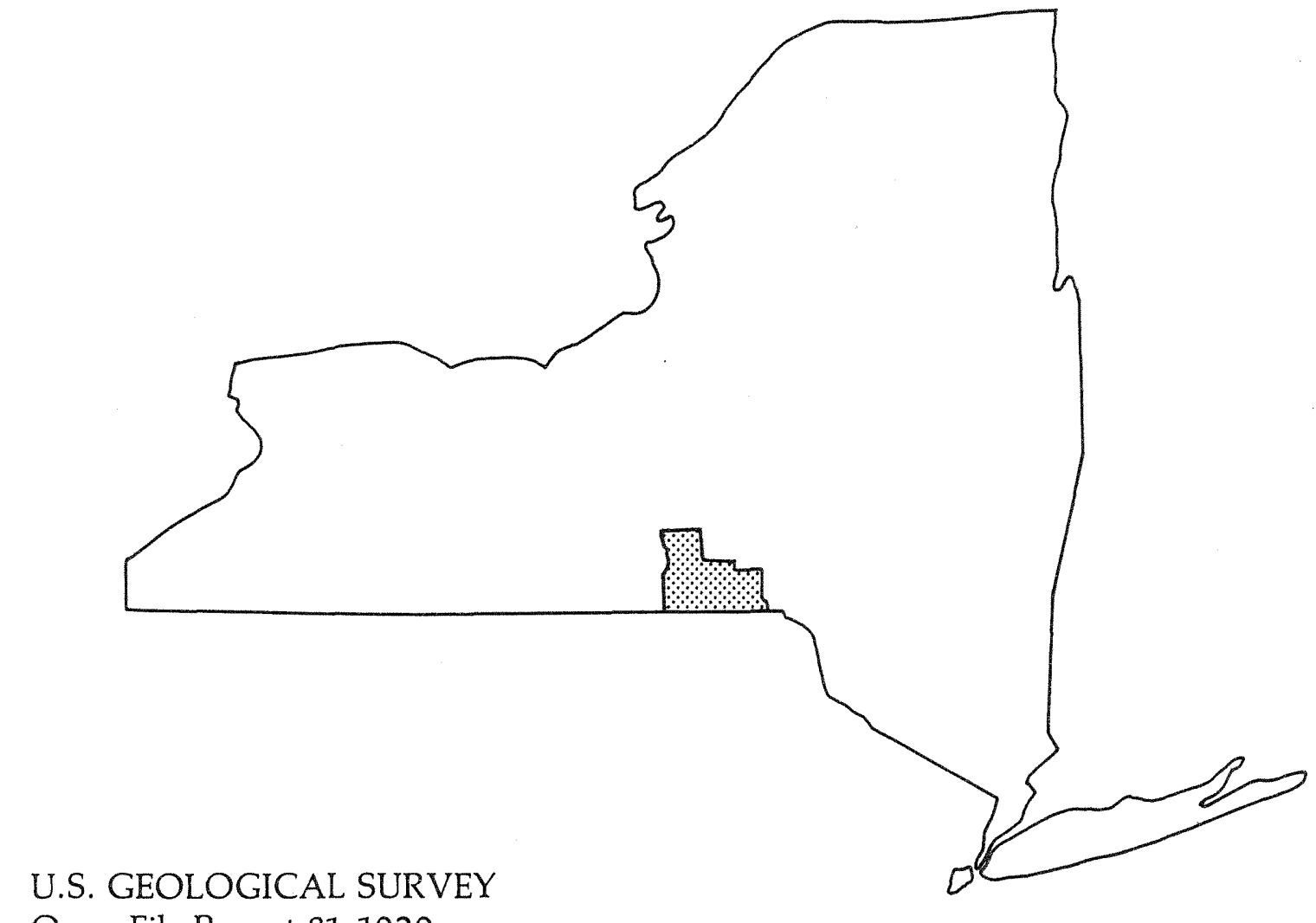

Open-File Report 81-1020

Prepared in cooperation with NEW YORK STATE DEPARTMENT OF TRANSPORTATION 


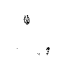


HYDRAULIC ANALYSIS OF CHENANGO RIVER,

BROOME COUNTY, NEW YORK IN RELATION

TO STATE HIGHWAY PLAN

by Bernard Dunn

U.S. GEOLOGICAL SURVEY

Open-File Report $81-1020$

Prepared in cooperation with

NEW YORK STATE DEPARTMENT OF TRANSPORTATION

Albany, New York

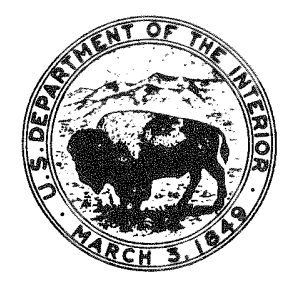

1981 


\author{
UNITED STATES DEPARTMENT OF THE INTERIOR \\ JAMES G. WATT, Secretary \\ GEOLOGICAL SURVEY \\ Dallas L. Peck, Director
}

For additional information write to:

U.S. Geological Survey

P.0. Box 1350

Albany, New York 12201

(518) 472-3107 


\section{CONTENTS}

Page

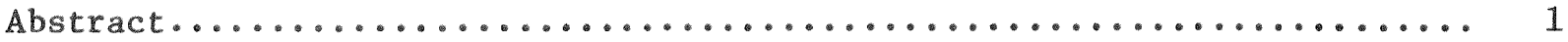

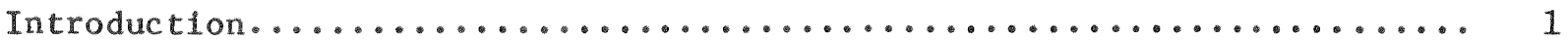

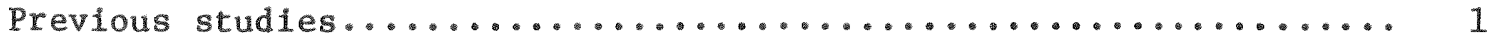

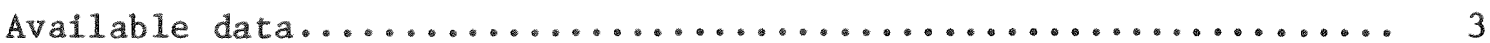

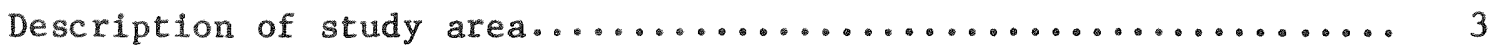

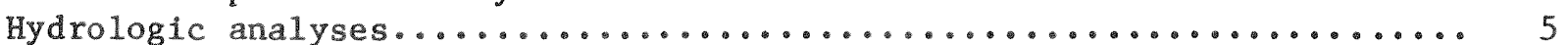

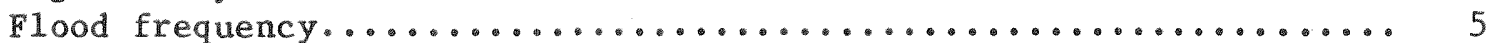

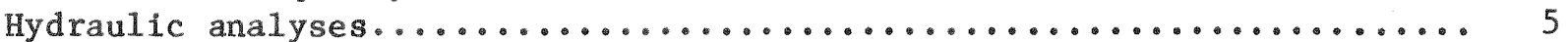

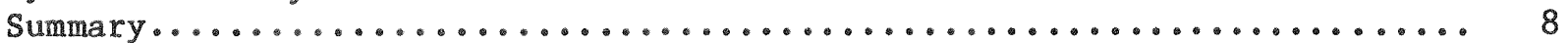

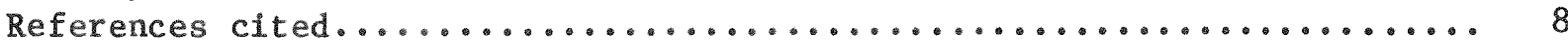

\section{ILLUSTRATIONS}

Figure 1. Map showing major geographic features of Broome County and location of area depicted in figure $2 \ldots \ldots \ldots \ldots \ldots . . . .$.

2. Map showing location of proposed highway............... 4

\section{TABLES}

Table 1. Water-surface elevations and mean velocity of 50-year

flood of Chenango River near Fenton and Chenango.........

2. Water-surface elevations and mean velocity of 100-year

flood of Chenango River near Fenton and Chenango.........

\section{CONVERSION FACTORS AND ABBREVIATIONS}

The following factors may be used to convert inch-pound units of measurement in this report to International System (SI) metric units.

$\begin{array}{lcl}\text { Multiply } & \text { by } & \text { To obtain SI units } \\ \text { mile (mi) } & 1.609 & \text { kilometer }(\mathrm{km}) \\ \text { square mile (mi2) } & 2.590 & \text { square kilometer }\left(\mathrm{km}^{2}\right) \\ \text { cubic feet per second } & .02832 & \text { cubic meters per second } \\ \quad(\mathrm{ft} 3 / \mathrm{s}) & & \left(\mathrm{m}^{3} / \mathrm{s}\right) \\ \text { foot }(\mathrm{ft}) & .3048 & \text { meter }(\mathrm{m})\end{array}$





\title{
Hydraulic Analysis of Chenango River, Broome County, New York in Relation to State Highway Plan
}

\author{
By \\ Bernard Dunn
}

ABSTRACT

\begin{abstract}
Hydraulic analyses of the 50- and 100-year floods in a 3.2 mile-reach of the Chenango River in the towns of Fenton and Chenango were made to deternine the effects of two altemative bridge designs on flood levels. Neither design would cause more than a 0.1-foot increase in water level of the 50-year flood nor more than a 0.2-foot increase in water level of the 100-year flood above levels that would occur during these floods under present channel conditions.
\end{abstract}

The discharges used in the analyses were 55,200 cubic feet per second for the 50-year flood and 63,000 cubic feet per second for the 100-year flood. Mean flow velocities and watersurface elevations at 17 cross sections are given for both bridge designs and are compared with those that would occur under present conditions.

\section{INTRODUCTION}

The New York State Department of Transportation (NYSDOT) plans to construct a new highway that would include a new bridge over the Chenango River in the towns of Fenton and Chenango, about 1,400 ft north of the Port Dickinson village boundary ( $f i g .1$ ). The plan also includes replacement of the present State Highway $12 \mathrm{~A}$ bridge, $2.2 \mathrm{mi}$ farther upstream, with a new one of the same size.

As part of a cooperative agreement with NYSDOT, a study was made to determine the effect the additional bridge would have on the water levels and flow velocity of a 50- and 100-year flood in the 3.2-mile reach upstream from the Port Dickinson village boundary. Two bridge designs were analyzed: one with a 1,000-foot opening and one with a 1,800-foot opening.

\section{Previous Studies}

Studies made by Dunn $(1972,1974$ ) and Dunn and Lumia (1977) addressed the hydraulic effects that several different bridge alinements in this reach would have on flood flows. This reach has been analyzed in three other studies: two flood-insurance studies made for the towns of Fenton and Chenango, (Federal Emergency Management Agency, 1980a, 1980b) provided water surface profiles of the 10-, 50-, 100-, and 500-year floods, and a flood-plain information report (U.S. Army Corps of Engineers, 1971) provided profiles of the standard project flood and intermediate reglonal flood. 


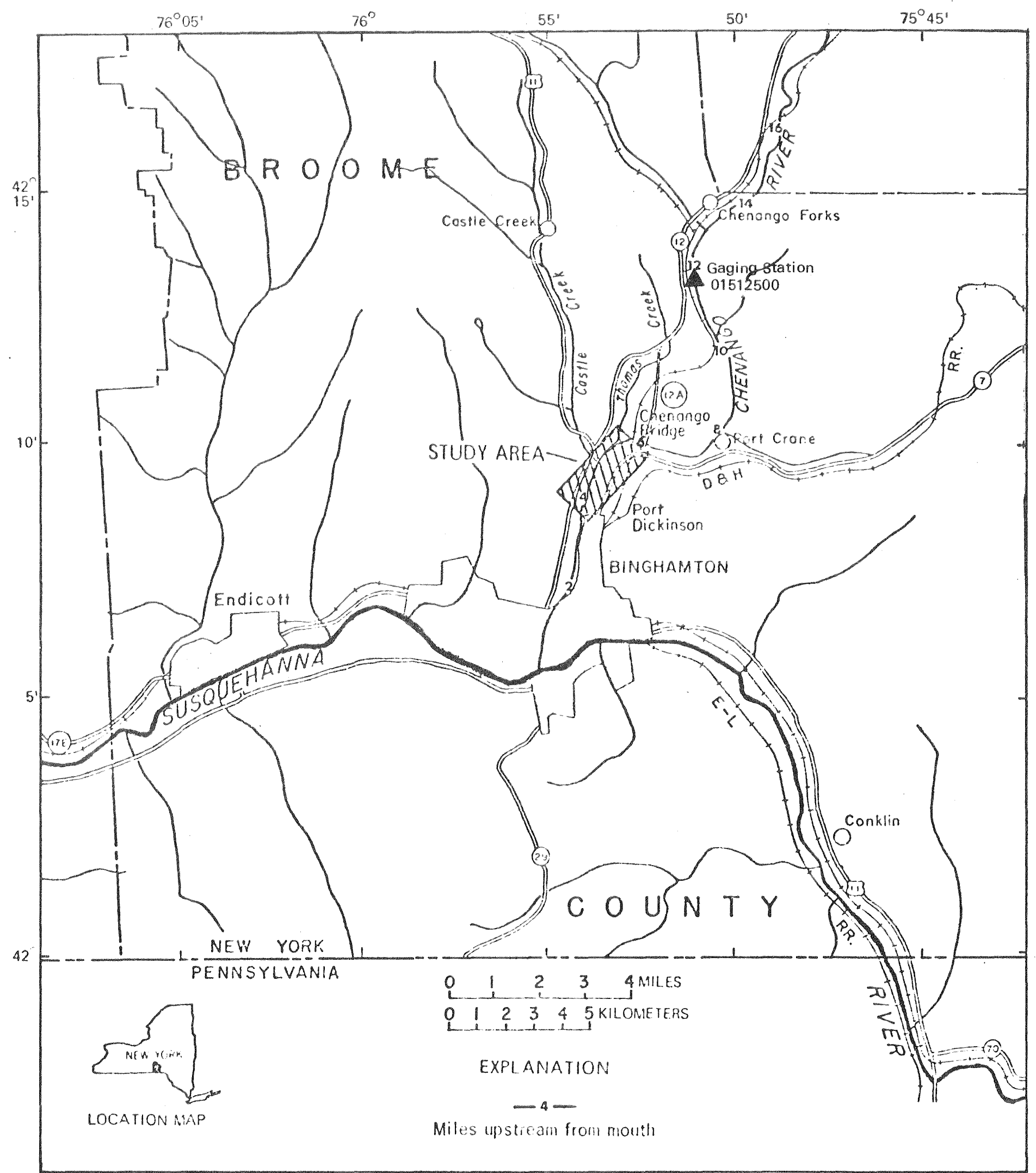

Busse frum U.S. Amy Conps of Engimers, Baltimore Districe, 1971

Figure 1.--Major geographic features of Broome County and location of area depicted in figure 2. 


\section{Avallable Data}

The data used in this study include:

1. Cross sections of the Chenango River flood plain, determined by photogrammetric methods from aerial photographs taken in December 1978 (Federal Emergency Management Agency, 1980a, 1980b).

2. Below-water cross sections of the river channel, obtained from the U.S. Army Corps of Engineers (1971) and the New York State Department of Transportation, Binghamton (written commun., June 13, 1973).

3. Plan drawings furnished by the New York State Department of Transportation.

4. Streamflow data collected by the U.S. Geological Survey during floods and field investigations.

5. Elevations at the downstream end of the reach, obtained from the stagedischarge relationship developed for the Town of Dickinson Flood Insurance Study (Federal Emergency Management Agency, 1977).

Al1 elevations are referenced to the National Geodetic Vertical Datum of 1929 (NGVD), formerly referred to as Mean Sea Level Datum of 1929.

\section{Description of Study Area}

The $3.2 \mathrm{mile}$ reach studied lies between Chenango Bridge and Port Dickinson (fig. 1). The drainage area at the downstream (south) end of the study reach is 1,593 square miles. The area is suburban with transportation facilities along the left (east) bank. Much of the area is on high ground and not subject to flooding, but the low-lying areas in the broad flood plain are flood prone.

The channel is fairly straight upstream from the two bridges at the north end of the study reach--the Erie-Lackawanna Railroad bridge and the State Highway 1.2A bridge (fig. 2). Downstream from the rallroad bridge, the channel is straight for about $0.4 \mathrm{mlle}$, then bends $50^{\circ}$ to the left at the mouth of Thomas Creek, and then continues nearly straight through the remainder of the reach. About 0.4 mile downstream from Thomas Creek, Castle Creek enters the Chenango River from the right bank.

The low left bank, the principal flood plain, is lined with trees. During the growing season, the ground beyond the trees is covered with tall. grass and light brush at the upper end of the reach and heavier brush at the lower end. The right bank is flat near the river but within a few feet rises steeply, except in the Broadacres area. Both banks are steep near the Highway $12 \mathrm{~A}$ bridge.

The proposed highway (fig. 2) will be on the east side of the river and will replace or be adjacent to State Highway 7. Dual bridges will cross the river at an angle of about $35^{\circ}$ to the Chenango River about $1,400 \mathrm{ft}$ north of the Port Dickinson village boundary. A new Highway 12A bridge the same length as the present one is proposed just upstream from the present one. 


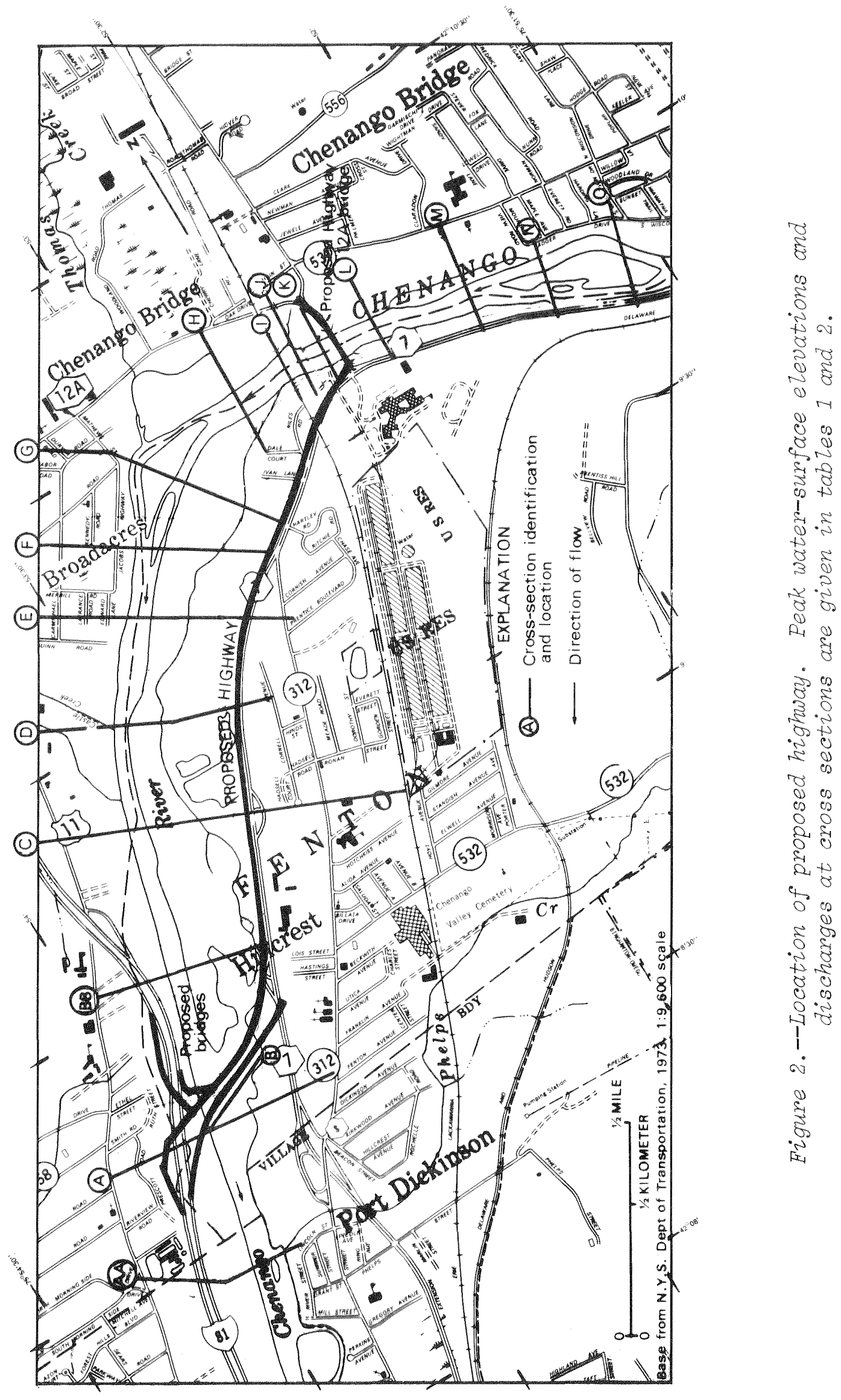




\section{HYDROLOGIC ANALYSES}

Records of flood stages and discharges at gaging station 01512500 on Chenango River, 1.2 miles downstream from the village of Chenango Forks (fig. 1) and 6 rilles upstream from the reach studied, have been collected by the Geological Survey since November 1912; the records for each year are published annully. The largest known flood since November 1912 occurred on July 8,1935 , when a peak discharge of $96,000 \mathrm{ft}^{3} / \mathrm{s}$ was recorded.

\section{Fiood Frequency}

The discharge-frequency relationship at a streamflow site is generally expressed in terms of recurrence interval or exceedance probability.

(Recurrence interval is the average tine interval between actual occurrences of a flood of equal or greater magnitude; exceedance probability, the reciprocal of recurrence interval, is the probability that a flood of specifled magnitude will be equaled or exceeded in any one year.) The floods selected for this analysis are the 50- and 100-year floods.

The discharge-frequency relationship for the gaging station near Chenango Forks was determined by the welghted averaging of estimates derived from a log-Pearson Type III analysis and reglonal regression equations. These estimates were applled to the reach studied. A 63-year period of record (1913-1975) of annual peaks recorded at the gage were used in the log-Pearson analysis. The reglonal regression equations and weighted-averaging technique were those given by Zembrzuski. and Dunn (1979).

Peak discharges of the 50- and 100-year floods in the study reach were computed to be $55,200 \mathrm{ft} 3 / \mathrm{s}$ and $63,000 \mathrm{ft} 3 / \mathrm{s}$, respectively. These discharges are in agreement with those reported in the flood-insurance studies completed for the towns of Chenango and Fenton (Federal Emergency Management Agency, $1980 \mathrm{a}$ and 1980b). The value for 100-year flood stage and discharge in the study area differs from that given in prevlous reports (Dunn, 1972 and 1974, and Dunn and Lumia, 1977) because newer methods were used for estimation of flood frequencles.

\section{HYDRAULIC ANALYSES}

Hydraulic characteristics of the entire reach were analyzed to provide water-surface profiles of the 50- and 100-year floods for the present channel and its proposed modification.

Near the proposed bxidge system north of the Port Dickinson village boundary, the highway will encroach on the flood plain between section $A A$ and $A$ (fig. 2) on the west side of the river and near section BB on the east side.

Water-surface proflles were developed by U.S. Geological Survey E431 and J635 step-backwater computer programs (Shearman, 1976 and Shearman, written commun., 1977). Starting water-surface elevations were obtained from the flood-insurance studies for the towns of Chenango and Fenton (Federal Emergency Management Agency, 1980a and 1980c). Results are presented in tables 1 and 2 . 
Table 1.--Water-surface elevations and mean velocity of 50-year flood of

Chenango River, near Fenton and Chenango, Broome County, N. Y.

\begin{tabular}{|c|c|c|c|c|c|c|}
\hline \multirow[b]{2}{*}{ Section1/ } & \multicolumn{2}{|c|}{ Present conditions } & \multicolumn{2}{|c|}{$\begin{array}{l}\text { Proposed } 1,000-f t \text { bridge } \\
\text { at section } \mathrm{B} \text { and Highway, } 12 \mathrm{~A} \\
\text { bridge replacement } 2 /\end{array}$} & \multicolumn{2}{|c|}{$\begin{array}{c}\text { Proposed } 1,800-\mathrm{ft} \text { bridge } \\
\text { at section } \mathrm{B} \text { and Highway } 12 \mathrm{~A} \\
\text { bridge replacement } 2 \text {. }\end{array}$} \\
\hline & $\begin{array}{l}\text { Water-surface } \\
\text { elevation }(\mathrm{ft})\end{array}$ & $\begin{array}{c}\text { Mean velocity } \\
(\mathrm{ft} / \mathrm{s})\end{array}$ & $\begin{array}{l}\text { Water-surface } \\
\text { elevation (ft) }\end{array}$ & $\begin{array}{c}\text { Mean velocity } \\
(\mathrm{ft} / \mathrm{s})\end{array}$ & $\begin{array}{l}\text { Water-surface } \\
\text { elevation ( } \mathrm{ft} \text { ) }\end{array}$ & $\begin{array}{l}\text { Mean velocity } \\
(\mathrm{ft} / \mathrm{s})\end{array}$ \\
\hline $\mathrm{AA}$ & 850.7 & 3.3 & 850.7 & 3.3 & 850.7 & 3.3 \\
\hline $\mathbb{A}$ & 851.2 & 3.9 & 851.2 & 4.5 & 851.2 & 4.5 \\
\hline B & - & - & 851.5 & 4.2 & 851.5 & 2.9 \\
\hline $\mathrm{BB}$ & 851.7 & 3.0 & 851.8 & 3.4 & 851.7 & 3.2 \\
\hline $\mathrm{C}$ & 852.3 & 4.6 & 852.4 & 4.6 & 852.3 & 4.6 \\
\hline D & 853.2 & 3.6 & 853.2 & 3.7 & 853.2 & 3.8 \\
\hline E & 853.9 & 3.2 & 853.9 & 3.4 & 853.9 & 3.4 \\
\hline F & 854.3 & 2.9 & 854.4 & 3.0 & 854.3 & 3.0 \\
\hline G & 854.8 & 4.0 & 854.9 & 4.0 & 854.9 & 4.0 \\
\hline $\mathrm{H}$ & 855.9 & 4.7 & 856.0 & 4.7 & 855.9 & 4.7 \\
\hline $\begin{array}{c}\text { I Railroad } \\
\text { bridge }\end{array}$ & 856.5 & 8.0 & 856.5 & 8.0 & 856.5 & 8.0 \\
\hline $\mathrm{J}$ & 857.0 & 6.5 & 857.0 & 6.4 & 857.0 & 6.5 \\
\hline $\begin{array}{r}\text { K Highway } \\
\text { bridge }\end{array}$ & 857.1 & 10.3 & 857.2 & 10.2 & 857.2 & 10.3 \\
\hline L & 859.2 & 5.1 & 859.1 & 5.1 & 859.1 & 5.2 \\
\hline M & 859.9 & 4.9 & 859.8 & 4.9 & 859.8 & 5.0 \\
\hline $\mathrm{N}$ & 860.6 & 5.3 & 860.5 & 5.3 & 860.5 & 5.3 \\
\hline 0 & 860.9 & 4.9 & 860.9 & 4.9 & 860.9 & 4.9 \\
\hline
\end{tabular}

$\frac{1 /}{2}$ Locations are given in figure 2 .

2/ Proposed replacement is identical to present bridge. 


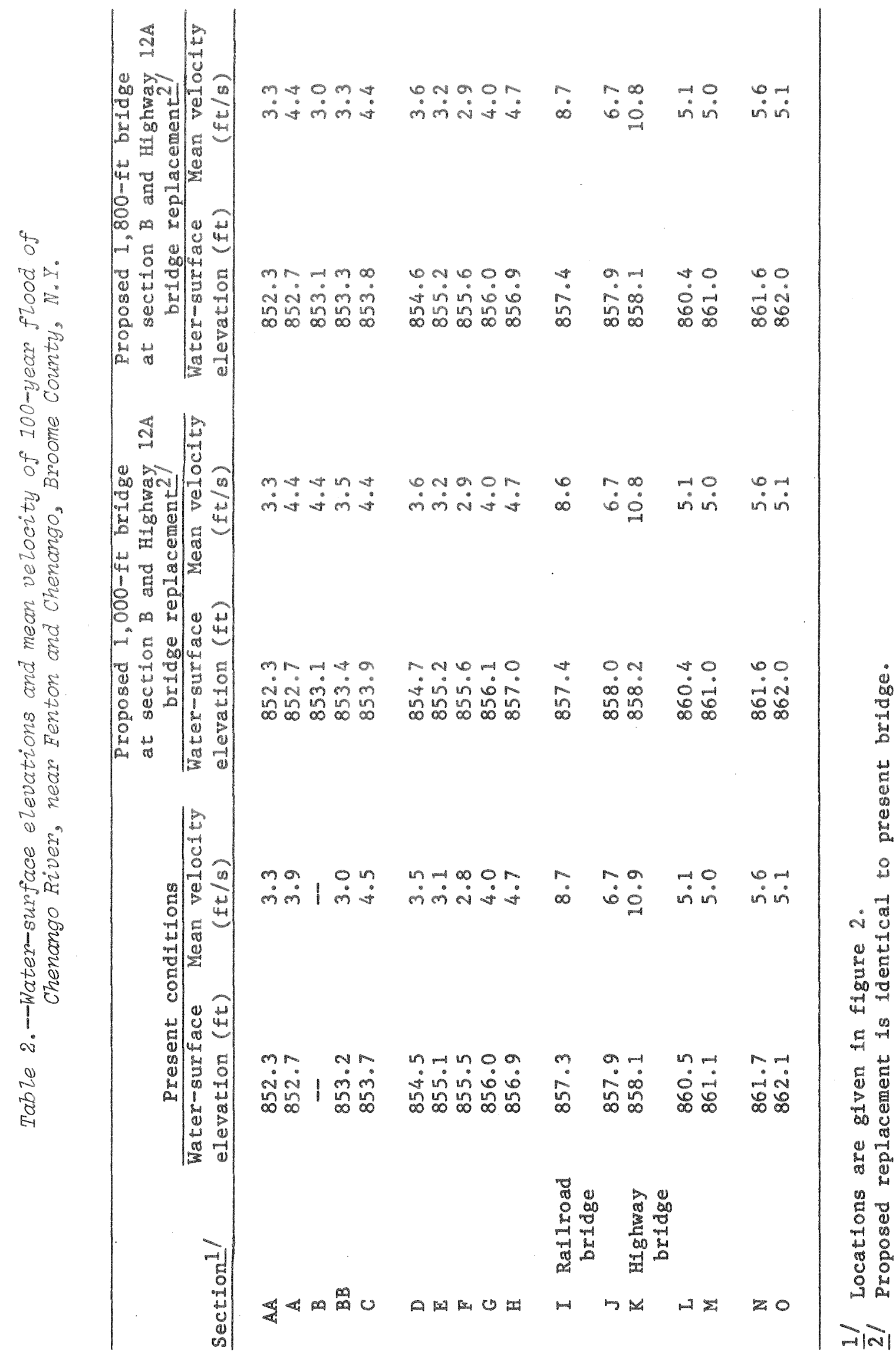


The maximum changes in water-surface elevation (in feet) that would result from the two bridge designs, in relation to the present condition, are as follows:

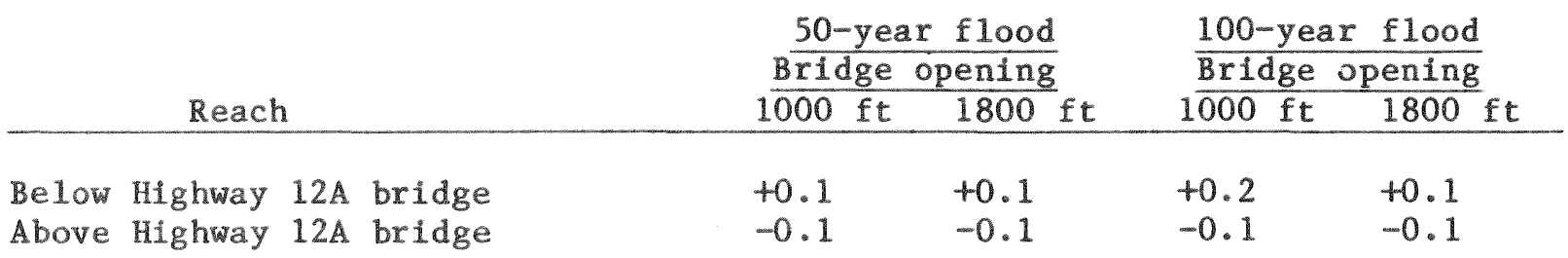

\section{SUMMARY}

This report presents 50 - and 100-year flood profiles that would result from a proposed highway along a reach of the Chenango River in the towns of Fenton and Chenango. The NYSDOT plan calls for replacement of the present State Highway $12 \mathrm{~A}$ bridge, near the upstream end of the reach and construction of a dual bridge at the downstream end of the reach, 1,400 ft upstream from the Port Dickinson village boundary. Two alternate designs for the dual bridge near Port Dickinson are considered-one with a 1,000-foot opening and one with a 1,800-foot opening. Flood conditions that would result from each alternative are compared with those of the present river channel.

Results of the study are summarized as follows:

50-year f1ood. - The plan with elther the 1,000-foot or the 1,800-foot bridge opening will increase the water-surface elevation of the 50-year flood by a maximum of 0.1 foot above present 50-year flood levels in the reach below the Highway $12 \mathrm{~A}$ bridge. Upstream from the Highway $12 \mathrm{~A}$ bridge, water-surface elevation of the 50-year flood will decrease by a maximum of 0.1 foot.

100-year flood.--The plan with the 1,000-foot bridge opening will increase the water-surface elevation of the 100-year flood by a maximum of 0.2 foot above present flood levels in the reach below the Highway $12 \mathrm{~A}$ bridge. The plan with the 1,800-foot bridge opening will cause a maximum increase of 0.1 foot above present flood levels. Upstream from the Highway $12 \mathrm{~A}$ bridge, water-surface elevation of the 100-year flood will decrease by a maximum of 0.1 foot regardless of which bridge design is used downstream.

\section{REFERENCES CITED}

Dunn, Bernard, 1972, Floodflow characteristics of the Chenango River at proposed interstate highway in towns of Fenton and Chenango, Broome County, New York: U.S. Geological Survey Open-File Rept., 7 p., 5 pls.

1974, Hydraulic analysis, Chenango River, Broome County, New York: U.S. Geological Survey Open-File Rept., 8 p., 6 pls. 


\section{REFERENCES CITED (continued)}

Dunn, Bernard, 1972, Floodflow characteristics of the Chenango River at proposed interstate highway in towns of Fenton and Chenango, Broome County, New York: U.S. Geological Survey Open-File Rept., 7 p., 5 pls.

1974, Hydraulic analysis, Chenango River, Broome County, New York: U.S. Geological Survey Open-File Rept., 8 p., 6 pls.

Dunn, Bernard and Lumia, Richard, 1977, Supplementary hydraulic analysis of the Chenango River, Broome County, New York, in relation to planned highway construction: U.S. Geological Survey Open-File Rept. 77-484, $8 \mathrm{p} \cdot, 1 \mathrm{pl}$.

Federal Emergency Management Agency, Federal Insurance Administration, 1977, Flood Insurance Study, Town of Dickinson, Broome County, New York: Washington, D.C.

1980a, Flood Insurance Study, Town of Chenango, Broome County, New York: Washington, D.C., 20 p., (in press).

1980b, Flood Insurance Study, Town of Fenton, Broome County, New York: Washington, D.C., 22 p., (In press).

Shearman, J. O., 1976, Computer program E431, user's manual, computer applications for step-backwater and floodway analysis: U.S. Geological Survey Open-File Rept., 103 p.

1977, Computer program J635, user's guide, step-backwater and floodway analysis: U.S. Geological Survey, unpub. rept. $48 \mathrm{p}$.

U.S. Army Corps of Engineers, 1971, Flood plain information, Chenango River, Broome County, New York: Baltimore, $29 \mathrm{p}$.

U.S. Geological Survey, 1960, Compllation of records of surface waters of the United States through September 1950--North Atlantic Slope Basins, New York to York River: U.S. Geological Survey Water-Supply Paper 1302, $679 \mathrm{p}$.

1964, Compilation of records of surface waters of the United States, October 1950 to September 1960--North Atlantic Slope Basins, New York to York River, U.S. Geological Survey Water-Supply Paper 1722, 578 p.

1961-74, Water resources data for New York, Part 1, Surface water records: U.S. Geological Survey Open-File Rept. (issued annually through 1974).

Water resources data for New York, v. 1, Upstate excluding Long Island: U.S. Geological Survey Water-Data Rept. (issued annually since 1975). 


\section{REFERENCES CITED (continued)}

U.S. Water Resources Counci1, 1977, Guidelines for determining flood flow frequency: U.S. Water Resources Counci1, Bu11. 17A, 25 p.

Zembrzuski, T. J., Jr. and Dunn, Bernard, 1979, Techniques for estimating magnitude and frequency of floods on rural unregulated streams in New York State, excluding Long Island: U.S. Geological Survey Water Resources Investigations 79-83, 66 p. 